PENGARUH LAMA PERENDAMAN ZPT ALAMI EKSTRAK BAWANG MERAH (Allium cepa)

PADAPERTUMBUHAN STEK BATANG SUKUN (Artocarpus altilis)

Laswi Irmayanti, Siti Hasan, Salam, Reyna Ashari, Aqshan Shadikin Nurdin, Arniana Anwar dan Ratna Uli Damayanti Sianturi

\title{
PENGARUH LAMA PERENDAMAN ZPT ALAMI EKSTRAK BAWANG MERAH PADA PERTUMBUHAN SETEK BATANG SUKUN (Artocarpus altilis Parkinson ex F.A.Zorn)
}

\author{
(The Effect of Soaking Duration in Natural PGR Shallot Extract on The Growth of Breadfruit \\ (Artocarpus altilis Parkinson ex F.A.Zorn) Fosberg Stem Cutting) \\ *Laswi Irmayanti', Siti Hasan², Salam², Reyna Ashari', Aqshan Shadikin Nurdin', Arniana \\ Anwar $^{3}$ dan/and Ratna Uli Damayanti Sianturi ${ }^{4}$ \\ ${ }^{1)}$ Program Studi Kehutanan, Fakultas Pertanian, Universitas Khairun \\ Jl.Jusuf Abdurahman, Telp (0921) 3110908, Gambesi, Ternate, Maluku Utara, Indonesia \\ ${ }^{2}$ Program Studi Kehutanan, Sekolah Tinggi Pertanian Labuha \\ Jl.Raya Wayamiga, Telp (0927) 2321573, Bacan Timur, Halmahera Selatan, Maluku Utara, Indonesia \\ ${ }^{3)}$ Fakultas Kehutanan, Universitas Papua, Jl.Gunung Salju, Manokwari, Papua Barat, Indonesia \\ ${ }^{4)}$ Balai Penelitian dan Pengembangan Teknologi Perbenihan Tanaman Hutan \\ Jl.Pakuan Ciheuleut PO Box 105, Telp.(0251) 8327768, Bogor, Jawa Barat, Indonesia \\ e-mail: laswii88@gmail.com
}

Naskah masuk: 23 September 2021; Naskah direvisi: 25 Oktober 2021; Naskah diterima: 6 Desember 2021

\begin{abstract}
Breadfruit (Artocarpus altilis Parkinson ex F.A.Zorn_) in Indonesia is generally seedless, so it is difficult to develop it generatively with seeds. The alternative is by vegetative propagation by cuttings. An important factor to ensure the survival of a cutting is the growth of shoots and roots that can be stimulated with plant growth regulators (PGR). Natural PGR that can be used to stimulate the growth of roots and cuttings is shallot extract. This study aimed to examine the effect of soaking duration into shallot extract on root and shoot growth of breadfruit stem cuttings. Breadfruit cuttings were taken in Madapolo Village, Obi District, South Halmahera Regency, North Maluku Province. The treatment applied was the difference in the soaking duration of the breadfruit stem cuttings into the shallot extract solution. The durations applied were 0 minutes (control), 10 minutes, 20 minutes, and 30 minutes. The highest number of shoots was in the control plant ( 0 minutes), while the highest shoot length was in the soaking treatment for 30 minutes. Likewise for the number and length of roots, soaking for 30 minutes gave the highest results. The duration of soaking the breadfruit stem cuttings into shallot extract significantly affected the growth of breadfruit shoots and roots.
\end{abstract}

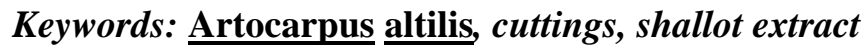

\begin{abstract}
Sukun (Artocarpus altilis Parkinson ex F.A.Zorn) yang ada di Indonesia umumnya adalah tanpa biji. Sehingga sangat sulit untuk dikembangkan secara generatif dengan biji. Alternatifnya adalah dengan perkembangbiakan secara vegetatif dengan setek. Faktor penting untuk menjamin kelangsungan hidup suatu setek adalah pembentukan tunas dan akar yang dapat dirangsang dengan zat pengatur tumbuh (ZPT). Salah satu ZPT alami yang dapat digunakan utuk merangsang pertumbuhan akar dan setek adalah ekstrak bawang merah. Penelitian ini adalah untuk mengetahui lama perendaman ekstrak bawang merah terhadap pertumbuhan akar dan tunas setek batang sukun Pengambilan bahan setek sukun dilakukan di kawasan Desa Madapolo, Kecamatan Obi, Kabupaten Halmahera Selatan, Provinsi Maluku Utara. Perlakuan yang diterapkan adalah perbedaan lama perendaman bahan setek batang sukun ke dalam larutan ekstrak bawang merah. Lama perendaman yang diterapkan sebanyak 4 perlakuan, yaitu: 0 menit (kontrol), 10 menit, 20 menit, dan 30 menit. Pengamatan pertumbuhan tunas setek dilakukan selama 12 minggu dan pengamatan akar dilakukan pada akhir pengamatan. Hasil pengamatan menunjukkan bahwa lama perendaman ZPT alami ekstrak bawang merah berpengaruh terhadap pertumbuhan tunas dan akar setek. Jumlah tunas terbanyak pada perlakuan tanpa perendaman ekstrak bawang merah, sedangkan panjang tunas yang tertinggi adalah pada perlakuan perendaman ekstrak bawang merah selama 30 menit, demikian pula untuk jumlah dan panjang akar.
\end{abstract}

Kata kunci : Artocarpus altilis, ekstrak bawang merah, lama perendaman, setek sukun

*Kontribusi penulis: Laswi Irmayanti sebagai kontributor utama

() 2021 BPTPTH All rights reserved. Open access under CC BY-NC-SA license.doi: //doi.org/10.20886/bptpth.2020.9.2.97-106 


\section{PENDAHULUAN}

Sukun (Artocarpus altilis Parkinson ex F.A.Zorn Fosberg) merupakan salah satu jenis Hasil Hutan Bukan Kayu penghasil buah dari genus Artocarpus famili Moraceae, tanaman asli Indonesia tersebar luas dari Aceh sampai Papua (Adinugraha \& Kartikawati, 2012). Buah sukun memiliki kandungan gizi yang tinggi (Adinugraha, Kartikawari, Setiadi, \& Prastyono, 2014; Anam, 2019) dan semua bagiannya dapat dimanfaatkan oleh manusia (Estalansa, Yuniastuti, \& Hartati, 2018). Beberapa daerah menyebut sukun dengan nama yang berbeda-beda, hal tersebut menunjukkan bahwa sukun merupakan buah yang tidak asing lagi dalam kehidupan orang Indonesia, seperti di Aceh (sakon), Batak (hatopul), Madura (sokon), dan Makassar (makara) (Angkasa \& Nazaruddin, 1994), serta amo di Maluku Utara.

Tanaman sukun digolongkan menjadi sukun yang berbiji (breadnut) dan yang tanpa biji (breadfruit) (Sikarwar et al., 2014; FAO, 2015) sedangkan yang ada di Indonesia pada umumnya sukun tanpa biji. Hal ini menyebabkan sukun sangat sulit untuk dikembangkan secara generatif dengan biji, sehingga alternatifnya adalah dengan perkembangbiakan secara vegetatif. FAO (2015) melaporkan bahwa sistem perakaran sukun tanpa biji bersifat adventif karena spesies ini diperbanyak secara vegetatif, misalnya dengan tunas adventif dan kultur jaringan maupun dengan setek.

Faktor penting untuk menjamin keberhasilan setek adalah pembentukan akar dan tunas. Pertumbuhan akar dan tunas pada setek dapat dirangsang dengan zat pengatur tumbuh (ZPT) (Muslimah, Jalil, Hadianto, Sarwanidas, \& Hasan, 2015). Menurut Istyantini (1996), penggunaan ZPT alami lebih menguntungkan dibandingkan dengan ZPT sintetis. Salah satu sumber ZPT alami yang dapat digunakan dalam pembibitan dengan setek adalah ekstrak bawang merah (Allium cepa L) karena ekstrak bawang merah mengandung ZPT yang mempunyai fungsi mirip dengan IAA (Indole Acetic Acid). IAA adalah hormon auksin yang paling aktif untuk berbagai tanaman dan berperan penting dalam memacu pertumbuhan akar setek (Alimudin, Syamsiah, \& Ramli, 2017). Ekstrak bawang merah dengan konsentrasi $75 \%$ berpengaruh terhadap umur muncul tunas, tinggi tunas, jumlah daun, jumlah tunas dan panjang akar setek (Ramli \&Alimudin, 2016; Syofia, Zulhida, \& Irfan, 2017; Rifai \& Wulandari, 2020; Syofia et al. 2017). Namun, belum dilakukan studi terkait lama perendaman ekstrak bawang merah pada bahan setek batang sukun. Studi tentang pengaruh dilakukan untuk mengetahui pengaruh lama perendaman bahan setek batang sukun dalam pertumbuhan akar dan tunas. 


\section{BAHAN DAN METODE}

\section{A. Bahan dan Alat}

Pengambilan bahan setek sukun dilakukan di Desa Madapolo, Kecamatan Obi, Kabupaten Halmahera Selatan, Provinsi Maluku Utara. Beberapa bahan yang digunakan dalam penelitian yaitu umbi bawang merah (Allium cepa L), akuades, pasir, tanah, kertas label, polybag dan plastik sungkup. Alat yang digunakan yaitu: gunting setek, sekop, parang, blender, gelas ukur, mistar dan tally sheet.

\section{B. Prosedur Penelitian}

\section{Penyiapan bahan setek}

Bahan setek disiapkan dari pohon sukun yang telah berbuah minimal tiga kali, dengan umur 5 tahun (Parotta, 1994). Bahan setek diambil dari pohon yang sama dengan menggunakan gunting setek. Panjang setek yang diambil adalah $15 \mathrm{~cm}$ dengan diameter 2 cm penelitian Ariefin, et al (2021). Bahan setek batang yang digunakan mempunyai ukuran yang hampir seragam.

\section{Pembuatan ekstrak bawang merah}

Umbi bawang merah yang digunakan sebanyak 10 buah berukuran besar dengan total berat 100 gram. Ekstrak bawang merah dibuat dengan cara menghancurkan umbi bawang merah menggunakan blender sampai halus dengan penambahan $200 \mathrm{~mL}$ akuades. Campuran tersebut kemudian disaring dan dituangkan pada gelas tempat perendaman setek.
Ekstrak bawang merah yang digunakan tersebut yaitu murni tanpa ada pengenceran, sehingga konsentrasinya adalah $100 \%$.

\section{Perendaman bahan setek pada ekstrak bawang merah}

Perlakuan yang diterapkan dalam penelitian adalah perbedaan lama perendaman bahan setek batang sukun ke dalam larutan ekstrak bawang merah.

Lama perendaman yang diterapkan sebanyak 4 perlakuan, yaitu: 0 menit (kontrol), 10 menit, 20 menit, dan 30 menit, dengan ulangan 3 kali, sehingga total unit percobaan berjumlah 12. Setiap unit percobaan berisi 1 setek batang.

\section{Penanaman setek}

Bahan setek batang sukun yang sudah direndam sesuai perlakuan kemudian ditanam dalam polybag dengan media tanam campuran tanah dan pasir (perbandingan 1:1, v/v). Setek ditanam dengan kedalaman $5 \mathrm{~cm}$. Setek yang telah ditanam kemudian disungkup dengan plastik transparan untuk mengurangi penguapan. Pemeliharaan setek dilakukan dengan penyiraman rutin setiap pagi dan sore serta pembersihan gulma.

\section{Pengamatan pertumbuhan setek}

Variabel yang diamati dalam penelitian ini adalah jumlah tunas, panjang tunas, jumlah akar, dan panjang akar setek. Pengamatan tunas dilaksanakan setiap minggu selama 12 minggu. Pengamatan akar dilakukan pada akhir pengamatan. 


\section{Analisis Data}

Rancangan percobaan yang digunakan dalam penelitian ini adalah Rancangan Acak Lengkap satu faktor yang mengacu pada Mattjik dan Sumertajaya (2013), serta Gomez dan Gomez (2007). Analisis sidik ragam untuk mengetahui yang digunakan untuk menguji pengaruh perlakuan lama perendaman terhadap variabel pertumbuhan setek yang diamati adalah analisis sidik ragam yang mengacu pada Mattjik dan Sumertajaya (2013). Apabila perlakuan memberikan pengaruh nyata pada variabel yang diukur, maka dilanjutkan dengan uji jarak berganda (duncan's multiple range test-DMRT) ( Gomes \& Gomes, 2007). Apabila perlakuan memberikan pengaruh nyata pada variabel yang diukur, maka dilanjutkan dengan uji jarak berganda Duncan (duncan's multiple range test-DMRT) (Gomes \& Gomes, 2007).

Model matematis yang digunakan adalah sbb.:

$$
Y_{i j}=\mu+R_{i}+\varepsilon_{i j}
$$

Keterangan:

$\mathrm{Y}_{\mathrm{ij}}=$ variabel yang diukur

$\mu=$ rata-rata umum

$\mathrm{R}_{\mathrm{i}}=$ efek perlakuan ke $\mathrm{i}$,

$\varepsilon_{\mathrm{ij}}=$ random eror pada pengamatan ke $\mathrm{i}$ dan ulangan ke $\mathrm{j}$

\section{HASIL DAN PEMBAHASAN}

\section{A. Hasil}

Hasil penelitian disajikan pada Gambar 1 yang menunjukkan pertumbuhan tunas setek selama pengamatan. Jumlah tunas terbanyak adalah pada perlakuan tanpa perendaman ekstrak bawang merah atau kontrol (0 menit). Pada semua perlakuan, tunas setek mulai muncul di minggu pertama dan jumlahnya terus bertambah hingga minggu kelima.

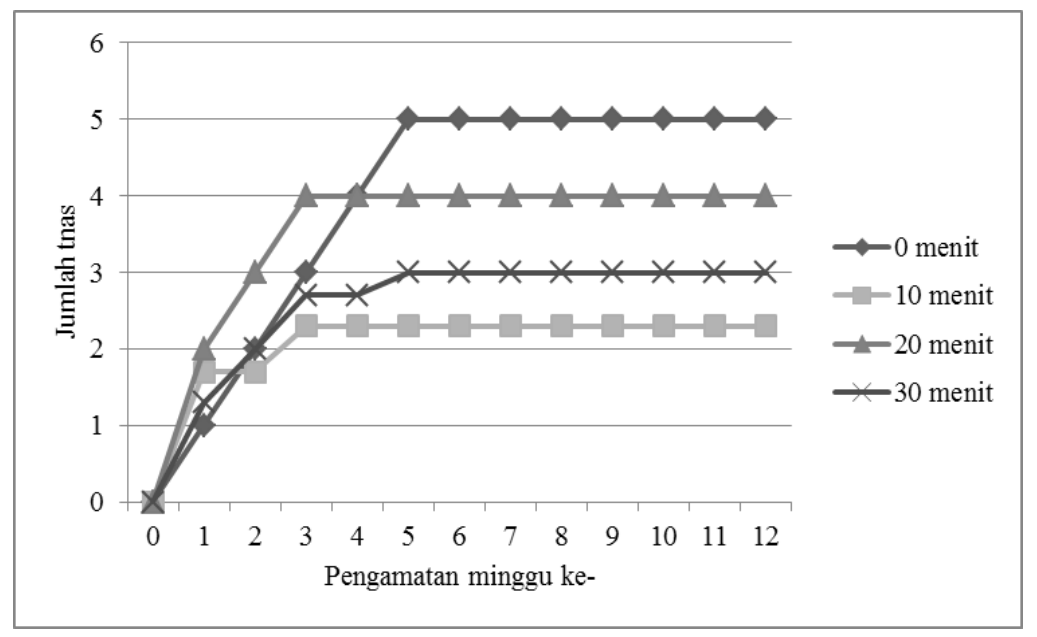

Gambar(Figure) 1. Pengamatan jumlah tunas setek sukun (Artocarpus altilis) setiap minggu pada perendaman ekstrak bawang merah (Number of shoots of breadfruit (Artocarpus altilis) cuttings in each shallot extract soaking treatment for 12 weeks of observation) 
Jumlah tunas setek sukun di akhir pengamatan berada pada rentang 2 tunas -5 tunas dengan jumlah terbanyak ditunjukkan oleh perlakuan kontrol. Gambar 2 menunjukkan kemunculan jumlah tunas menurun pada durasi perendaman yang lebih lama. Pengecualian pada setek dengan perlakuan perendaman 10 menit yang jumlah tunasnya lebih sedikit dibandingkan perendaman 20 dan 30 menit.

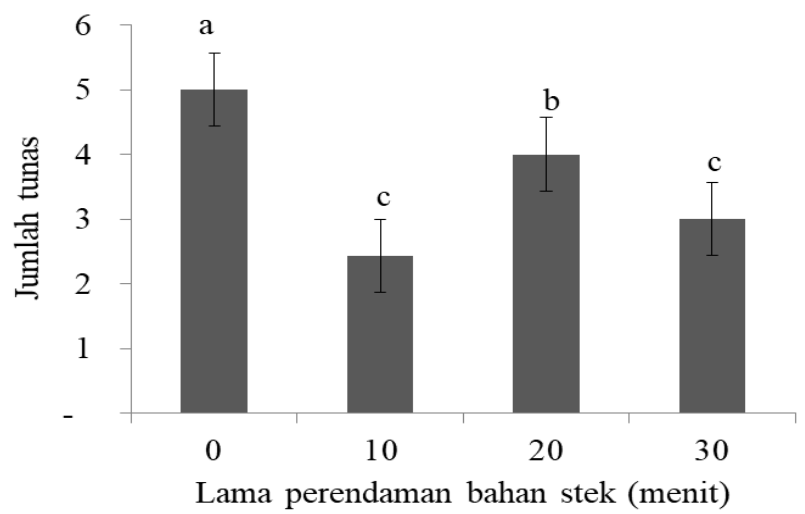

Gambar(Figure) 2. Jumlah tunas setek sukun (Artocarpus altilis) pada setiap perlakuan perendaman ekstrak bawang merah (Number of shoots of breadfruit (Artocarpus altilis) cuttings in each shallot extract soaking treatment)

Panjang tunas yang tertinggi adalah pada perlakuan perendaman ekstrak bawang merah selama 30 menit (Gambar 3), pertumbuhannya sangat pesat jika dibandingkan dengan setek pada tiga perlakuan lainnya. Setek pada perlakuan perendaman 20 menit, 10 menit dan kontrol menunjukkan pertumbuhan panjang tunas yang cenderung seragam. Meskipun demikian, tunas setek perlakuan 20 menit tumbuh lebih panjang di enam minggu pertama dibandingkan perlakuan kontrol dan 10 menit.

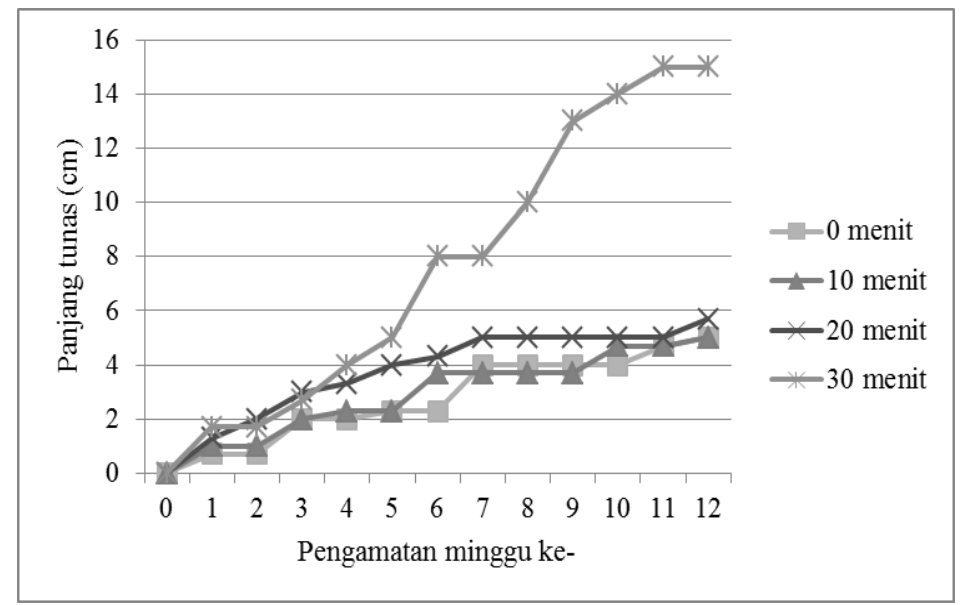

Gambar (Figure) 3. Pengamatan panjang tunas setek sukun (Artocarpus altilis) setiap minggu pada perendaman ekstrak bawang merah (Shoot length of breadfruit (Artocarpus altilis) cuttings in each shallot extract soaking treatment for 12 weeks of observation) 
Panjang tunas di akhir pengamatan adalah sepanjang $5 \mathrm{~cm}-15 \mathrm{~cm}$ dengan panjang terbesar pada setek yang direndam selama 30 menit (Gambar 4). Ketiga perlakuan lainnya memiliki panjang serupa, yaitu $5 \mathrm{~cm}$. Setek pada perlakuan perendaman 20 menit sedikit lebih panjang dari kontrol dan perendaman 10 menit, selisihnya sekitar $0,8 \mathrm{~cm}$.

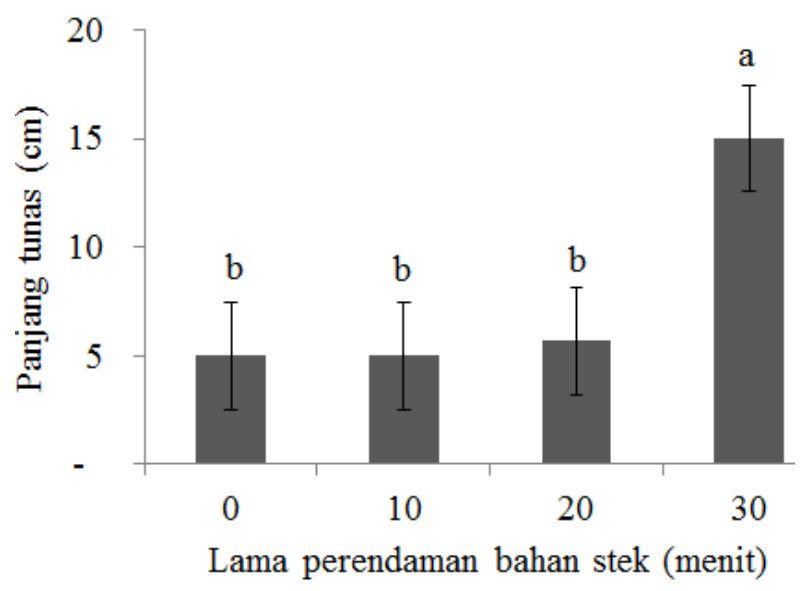

Gambar(Figure) 4. Panjang tunas setek sukun (Artocarpus altilis) pada setiap perlakuan perendaman ekstrak bawang merah (Shoot length of breadfruit (Artocarpus altilis) cuttings in each shallot extract soaking treatment)

Akar setek sukun pada setiap perlakuan menit dengan jumlah 50 akar. Akar pada perendaman berjumlah lebih dari 20 cabang di perlakuan kontrol sebanyak 30 akar, sementara akhir pengamatan (Gambar 5). Jumlah perlakuan lainnya memiliki jumlah yang lebih terbanyak pada perlakuan perendaman 30 sedikit keduanya hampir sama.

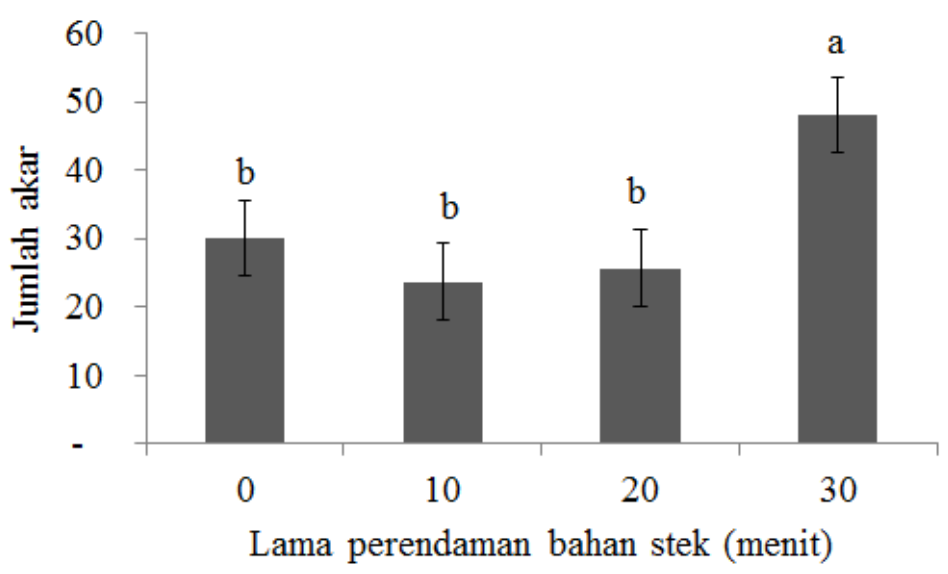

Gambar(Figure) 5. Jumlah akar setek sukun (Artocarpus altilis) pada setiap perlakuan perendaman ekstrak bawang merah (Number of roots of breadfruit (Artocarpus altilis) cuttings in each shallot extract soaking treatment) 
Akar setek sukun setelah dua minggu memiliki panjang kurang dari $3 \mathrm{~cm}$ pada setiap perlakuan perendaman (Gambar 6). Akar setek suku tumbuh lebih panjang pada durasi perendaman yang lebih lama. Nilai tertinggi ditunjukkan oleh perlakuan perendaman 30 menit dan 20 menit. Perlakuan kontrol dan perendaman 10 menit menghasilkan akar yang lebih pendek.

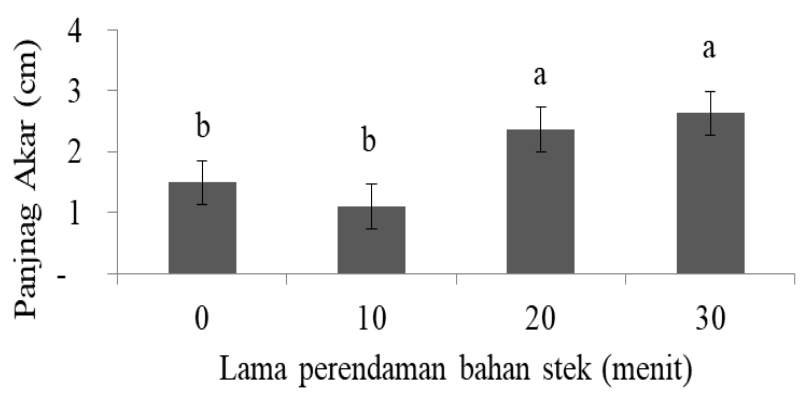

Gambar(Figure) 6. Panjang akar setek sukun (Artocarpus altilis) pada setiap perlakuan perendaman ekstrak bawang merah (Root length of breadfruit (Artocarpus altilis) cuttings in each shallot extract soaking treatment)

Hasil uji jarak berganda (Duncan's multiple range test - DMRT) menunjukkan bahwa semua perlakuan lama perendaman bahan setek pada ekstrak bawang merah memberikan pengaruh yang nyata terhadap pertumbuhan tunas dan akar setek sukun.

\section{B. Pembahasan}

Sepanjang siklus hidup tanaman mempertahankan kemampuan untuk menghasilkan organ baru melalui organogenesis (Xue, Liu, \& Zhang, 2020). Proses organogenesis pada tanaman di atas permukaan tanah dikontrol oleh jaringan meristem yang terorganisir, terbentuk, dan dipertahankan pada tunas pucuk-pucuk dan ketiak daun. Hasil penelitian menunjukkan bahwa jumlah tunas yang dihasilkan oleh bahan setek sukun pada perlakuan kontrol (tidak direndam dengan ekstrak bawang merah) memberikan hasil jumlah tunas tertinggi dan berbeda nyata dengan perlakuan lainnya. Seperti yang kita ketahui bahwa tunas dibedakan menjadi tunas apikal dan axilar (Leyser 2009).

Tunas apikal merupakan tunas yang berada diujung atas yang berisi meristem apikal dan menumbuhkan tanaman ke arah atas. Sedangkan tunas axilar merupakan tunas yang muncul dan berada di ketiak daun dan tumbuh memanjang ke arah samping untuk membentuk cabang-cabang tanaman. Jumlah tunas yang lebih banyak pada setek sukun tanpa perendaman, ini didominasi oleh tunas axilar, sedangkan setek dengan perendaman ekstrak bawang merah didominasi oleh tunas apikal. Hal ini disebabkan oleh pengaruh 
auksin yang terdapat pada ekstrak bawang merah mampu menghambat pertumbuhan tunas axilar, sehingga yang muncul hanya tunas apikal. Saini, Sharma, Kaur, \& Pati (2013) menyatakan bahwa auksin yang dihasilkan oleh tunas apikal (atau ujung tumbuh) berdifusi ke bawah dan menghambat perkembangan pertumbuhan tunas axilar.

Dua golongan zat pengatur tumbuh yang sangat penting adalah sitokinin dan auksin (Arimarsetiowati \& Ardiyani, 2012). Auksin adalah hormon tanaman yang diproduksi di ujung batang yang mendorong pemanjangan sel. Anam (2019) melaporkan bahwa pertumbuhan tanaman sangat dipengarui oleh banyaknya kandungan auksin di dalam tanaman (endogen). Pemberian auksin dari luar (eksogen) mampu memacu aktivitas auksin endogen sehingga dapat mempercepat tumbuhnya tunas. Secara umum auksin merupakan senyawa dengan ciri-ciri mempunyai kemampuan dalam mendukung terjadinya pemanjangan sel pada pucuk. Paque dan Weijers (2016) melaporkan bahwa auksin mengontrol pemanjangan, pelebaran, dan diferensiasi sel. Auksin merupakan molekul penting yang mengontrol hampir setiap aspek perkembangan tanaman.

Aplikasi ekstrak bawang merah sebagai zat pengatur tumbuh setek sukun memberikan pengaruh yang baik bagi pembentukan akar bahan setek. Bawang merah mengandung hormon auksin (IAA, 2,4-D, dan NAA) serta sitokinin 6-BAP) dan aplikasinya pada tanaman dapat membantu pertumbuhan akar (Yunindanova, Budiastusi, \& Purnomo, 2018; Arimarsetiowati \& Ardiyani, 2012). Hormon auksin dalam bawang merah mampu menginduksi pembentukan akar baru dengan memecah dominansi akar apikal. Saini et al. (2013) melaporkan bahwa perkembangan akar yang dipicu oleh auksin merupakan perpaduan antara hormon endogen dan eksogen. Auksin merupakan pusat pertumbuhan dan perkembangan akar, yang juga bersinergi dengan hormon lain dalam mendukung pertumbuhan. Hal ini menunjukkan adanya kompleksitas pada perkembangan akar yang disebabkan oleh auksin.

Pada perlakuan perendaman 30 menit, akar yang dihasilkan memiliki panjang dan jumlah terbesar dibandingkan dua perlakuan lain serta kontrol. Durasi perendaman yang lebih panjang memungkinkan osmosis larutan ke dalam sel yang lebih besar. Pengaruh hormon auksin terhadap perkembangan akar bergantung pada dosis yang diberikan (Overvoorde, Fukaki, \& Beeckman, 2010). Dalam jumlah yang optimal, hormon auksin dapat merangsang perkembangan akar lateral, menunjukkan bahwa auksin berperan penting dalam inisiasi akar (Sachs, 2005). Aplikasi hormon auksin eksogen dalam jumlah berlebih justru akan menghambat pemanjangan akarnya 
(Tanimoto, 2005) dan meningkatkan produksi akar lateralnya yang berdampak pada morfologi akar tanaman (Balliu \& Sallku, 2017).

Auksin menginduksi pembentukan akar baru dengan memecah dominansi akar apikal. (Saini et al.) melaporkan bahwa perkembangan akar yang dipicu oleh auksin merupakan perpaduan antara hormon endogen dan eksogen. Auksin merupakan pusat pertumbuhan dan perkembangan akar, yang juga bersinergi dengan hormon lain dalam mendukung pertumbuhan. Hal ini menunjukkan adanya kompleksitas pada perkembangan akar yang disebabkan oleh auksin.

\section{KESIMPULAN}

Perlakuan lama perendaman dengan ekstrak bawang merah selama 30 menit memberikan respon terbaik terhadap panjang tunas, jumlah dan panjang akar pada setek akar sukun.

\section{UCAPAN TERIMA KASIH}

Penulis mengucapkan terima kasih kepada pemerintahan Desa Madapolo, Kecamatan Obi, Kabupaten Halmahera Selatan, Provinsi Maluku Utara yang memberikan izin dalam pengambilan sampel penelitian bahan setek sukun. Terima kasih penulis sampaikan juga kepada Bapak Saipul Riyadi, S.Hut (STP Labuha, Halmahera Selatan) atas masukan dan saran yang diberikan kepada penulis dalam penyempurnaan penulisan publikasi.

\section{DAFTAR PUSTAKA}

Adinugraha, H. A., \& Kartikawati, N. K. (2012). Variasi morfologi dan kandungan gizi buah sukun. Wana Benih, 13(2), 99-106.

Adinugraha, H. A., Kartikawati, N. K., Setiadi, D., \& Prastyono (2014). Pengembangan Teknik Budidaya Sukun (Artocarpus altilis) untuk Ketahanan Pangan. Bogor: PT.Penerbit IPB Press

Alimudin, Syamsiah, M., \& Ramli (2017). Aplikasi pemberian ekstrak bawang merah (Allium cepa) terhadap pertumbuhan akar setek batang bawah mawar (Rosa Sp.) varietas malltic. Journal of Agroscience, 7(1), 194-202

Anam, D. K. (2019). Pengaruh Macam Zat Pengatur Tumbuh dan Bahan Setek Terhadap Pertumbuhan Setek Sukun (Artocarpus altilis). BIOFARM: Jurnal Ilmiah Pertanian, 15(1), 31-36

Angkasa, S., \& Nazaruddin. (1994). Sukun dan Keluwih. Jakarta (ID): Penebar Swadaya.

Ariefin, M. N., Adinugraha, H. A., Basuki, B., \& Srilestari, R. (2021). Prosiding Seminar Nasional Fakultas Pertanian UNS Membangun Sinergi antar Perguruan Tinggi dan Industri Pertanian dalam Rangka Implementasi Merdeka Belajar Kampus Merdeka. Pertumbuhan stek batang empat kultivar sukun (Artocarpus altilis) dengan variasi panjang stek. (Vol. 5, No. 1, pp. 13181330).

Arimarsetiowati, R., \& Ardiyani, F. (2012). Pengaruh penanambahan auxin terhadap pertunasan dan perakaran kopi arabika perbanyakan somatik embriogenesis. Pelita Perkebunan, 28(2), 82-90

Balliu, A., Sallaku, G. (2017). Exogenous auxin improves root morphology and restores growth of grafted cucumber seedlings. Hort. Sci, 44(2), 82-90

Estalansa, H., Yuniastuti, E., \& Hartati, S. (2018). The diversity of breadfruit plants (Artocarpus 
altilis) based on morphological characters. Agrotech Res J, 2(2), 80-85

FAO [Food and Agriculture Organization of the United Nations]. (2015). Breadfruit and Breadnut orchard Establishment and Management, A manual for Commercial Production. Rome : Food and Agriculture Organization of the United Nations

Gomez, K. A., \& Gomez, A. A. (2007). Prosedur Statistik untuk Penelitian Pertanian. Sjamsuddin E, Baharsjah JS, penerjemah. Jakarta (ID): UI Press. Terjemahan dari: Statistical Procedures for Agricultural Research.

Istyantini, M. T. E. (1996). Pengaruh konsentrasi dan macam zat pengatur tumbuh alami terhadap setek pucuk berbagai varietas krisan (Chrysanthenum sp). Skripsi. Jurusan Agronomi. Fakultas Pertanian. Universitas Jember.

Leyser, O. (2009). The control of shoot branching: an example of plant information processing. Plant, Cell and Environment, 32, 694-703

Mattjik, A. A., \& Sumertajaya, I. M. (2013). Perancangan Percobaan dengan Aplikasi SAS dan Minitab. Bogor (ID): IPB Press.

Muslimah, Y., Jalil, M., Hadianto, W., Sarwanidas, T., \& Hasan, A. (2015). Pengaruh konsentrasi ekstrak bawang merah dan media tanam terhadap pertumbuhan setek mucuna (Mucuna bracteata). Jurnal Agrotek Lestari, 1(1), 4754.

Overvoorde, P., Fukaki, H., Beeckman, T. (2010). Auxin control of root development. Cold Spring Harb Perspect Biol 2010;2: a001537

Paque, S., \& Weijers, D. (2016). Q\&A: Auxin: the plant molecule that influences almost anything. BMC Biology, 14:67, DOI 10.1186/s12915-016-0291-0

Parotta, J. A. (1994). Artocarpus altilis (S.Park.) Fosb. SO-ITF-SM-71. University of Puerto Rico.
Ramli, \& Alimudi, M. (2016). Pengaruh konsentrasi ekstrak bawang merah (Allium серa) terhadap pertumbuhan akar setek batang bawah mawar (Rosa Sp.). Journal of Agroscience, 6(2), 70-77.

Rifai, M., \& Wulandari, R. (2020). Pengaruh ekstrak bawang merah terhadap pertumbuhan stump tanjung (Mimusops elengi L.). Jurnal Warta Rimba, 8(1), 28-33

Sachs, T. (2005). Auxin's role as an example of the mechanisms of shoot/root relations. Plant and Soils, 268, 13-19

Saini, S., Sharma, I., Kaur, N., \& Pati, P. K. (2013). Auxin : a master regulator in plant root development. Plant Cell Rep, DOI 10.1007/s00299-013-1430-5

Sikarwar, M. S., Hui, B. J., Subramaniam, K., Valeisamy, B. D., Yean, L. K., \& Balaji, K. (2014) A review on Artocarpus altilis (Parkinson) Fosberg (breadfruit). Journal of Applied Pharmaceutical Science, 4(08), 091097, DOI: 10.7324/JAPS.2014.40818

Syofia, I., Zulhida, R., \& Irfan, M. (2017). Pengaruh tingkat konsentrasi bawang merah (Allium cepa $\mathrm{L}$ ) terhadap pertumbuhan setek pucuk beberapa jenis jeruk asam (Citrus sp.). Agrium, 20(3), 177-184.

Tanimoto, E. (2005). Regulation of growth by plant hormones - roles for auxin and gibberellin. Plant Sci, 24(4), 249-265.

Xue, Z., Liu, L., \& Zhang, C. (2020). Regulation of soot apical meristem and axillary meristem development in plants. International Journal of Molecular Science, 21, 2917. doi: 10.3390/ijms21082917

Yunindanova, M. B., Budiastuti, M. S., \& Purnomo, D. (2018). In IOP Conference Series: Earth and Environmental Science. The analysis of endogenous auxin of shallot and its effect on the germination and the growth of organically cultivated melon (Cucumis Melo). (Vol. 215, No. 1, p. 012018). IOP Publishing. 